\title{
Wastewater, Sludge and Excreta Use in Developing Countries: An Overview
}

\author{
Blanca Jiménez, Pay Drechsel, Doulaye Koné, Akiça Bahri, \\ Liqa Raschid-Sally and Manzoor Qadir
}

\begin{abstract}
After introducing terms and terminology of wastewater, sludge and excreta use, the chapter highlights their global drivers and significance using examples from different parts of the developing world. It is useful in the discussion to differentiate between unplanned use of wastewater resulting from poor sanitation, and planned use which tries to address matters such as economic or physical water scarcity. Both types of wastewater use can have significant socio-economic benefits but also institutional challenges and risks which require different management approaches and, ideally, different guidelines. This diversity makes the current WHO Guidelines, which try to be global in nature, complex to understand and apply. Whilst planned reuse will remain the norm in countries that can afford treatment, most countries in the developing world are likely to continue to use non- or only partially treated wastewater, for as long as sanitation and waste disposal are unable to keep pace with urban population growth. However, there are options to link urban faecal sludge and wastewater management with urban food demands or other forms of resource recovery that provide opportunities to safely close the nutrient and water loops.
\end{abstract}




\section{Box 1.1 Definitions}

The term 'wastewater' as used in this book covers wastewater of different qualities, ranging from raw to diluted, generated by various urban activities:

- Urban wastewater is usually a combination of one or more of the following which makes it polluted water:

- Domestic effluent consisting of blackwater (excreta, urine and faecal sludge, i.e. toilet wastewater) and greywater (kitchen and bathing wastewater)

- Water from commercial establishments and institutions, including hospitals

- Industrial effluent where present

- Stormwater and other urban run-off.

- Treated wastewater is wastewater that has been processed through a wastewater treatment plant up to certain standards in order to reduce its pollution or health hazard; if this is not fulfilled; the wastewater is considered at best as partially treated.

- Reclaimed (waste)water or recycled water is treated wastewater that can officially be used under controlled conditions for beneficial purposes such as irrigation.

- Faecal sludge is the general term for the undigested or partially digested slurry or solid that results from the storage or treatment of blackwater in so-called on-site sanitation systems such as septic tanks, latrines, toilet pits, dry toilets, unsewered public toilets and aqua privies.

- Biosolids are treated sludge or the treated by-products of domestic and commercial sewage, wastewater and faecal sludge treatment that can be beneficially utilized as soil amendment and fertilizer. These residuals are treated to reduce their organic matter content, volume and/or mass, the pathogens and the vector attraction potential.

Source: Raschid-Sally and Jayakody (2008), modified

\section{INTRODUCTION}

Describing the present use of polluted water, excreta and sludge in the agricultural practices of developing countries is not an easy task. On the one hand, there is a lack of reliable and sufficient information and, on the other, the available information does not use uniform terms and units to describe these practices, making it difficult to compare data or establish global inventories. The common lack of data is in part due to the informal character of the practice or even, in some cases, to the intention not to disclose data. This may be done because either farmers fear difficulties when trading their produce or governments do not want to acknowledge what appears to be a malpractice. For these reasons, this chapter will firstly introduce some definitions of terms that will be used throughout the entire book and will secondly analyse existing information from different sources 
using, for the given reasons, non-standardized methods of reporting. Despite these limitations, the descriptions presented are useful to provide an idea of the extent of the use of wastewater, excreta and sludge for agricultural practices in low- and middle-income countries.

\section{BACKGROUND}

Land application of wastewater, sludge and excreta is a widespread practice with a long tradition in many countries around the world. For centuries, farmers in China used human and animal excrements as fertilizers. Wastewater and sewage sludge, just as manure, have also been used by the northern European and Mediterranean civilizations; for instance, wastewater was reused in the 14th and 15th centuries in the Milanese Marcites and in the Valencian huertas, respectively (Soulié and Tréméa, 1991). In many European and North American cities, wastewater was disposed of in agricultural fields before the introduction of wastewater treatment technologies to prevent pollution of water bodies. In Paris, for instance, the use of partially treated wastewater was common until the second part of the 1900s (Asano et al., 2007). In developing countries like China, Mexico, Peru, Egypt, Lebanon, Morocco, India and Vietnam, wastewater has been used as a source of crop nutrients over many decades (AATSE, 2004; Jiménez and Asano, 2008). Therefore, agricultural use of untreated wastewater has been associated with land application and crop production for centuries (Keraita et al., 2008). However, over the years, it has become less popular in developed countries with the improvement of treatment technologies and increased awareness of the environmental and health issues associated with the practice; by contrast, in developing countries, due to a variety of factors described later, farmers use it extensively, even drawing advantages to improve their livelihoods.

The oldest references to the use of excreta come from some Asian countries, where it was used to increase fish production through aquaculture (World Health Organization (WHO), 2006). Sludge management has only recently become an issue, even for developed countries, because the densely populated areas are producing such large amounts of sludge and excreta that natural assimilation into the environment is not possible, while space for stockpiling is limited (United Nations Human Settlements Programme (UNHSP), 2008). Moreover, management is complex and there is a lack of social support: people prefer to ignore what happens to excreta after it is disposed of into latrines - and they are uncomfortable if it is brought to their attention, be it in developed or developing countries (Snyman, 2008).

This chapter attempts to give an overview of the use of wastewater, excreta and faecal sludge in agriculture; to characterize their use, the benefits derived and the costs involved, particularly regarding health consequences; and to provide perceptions around such uses and perspectives for the future. It is to be noted that 


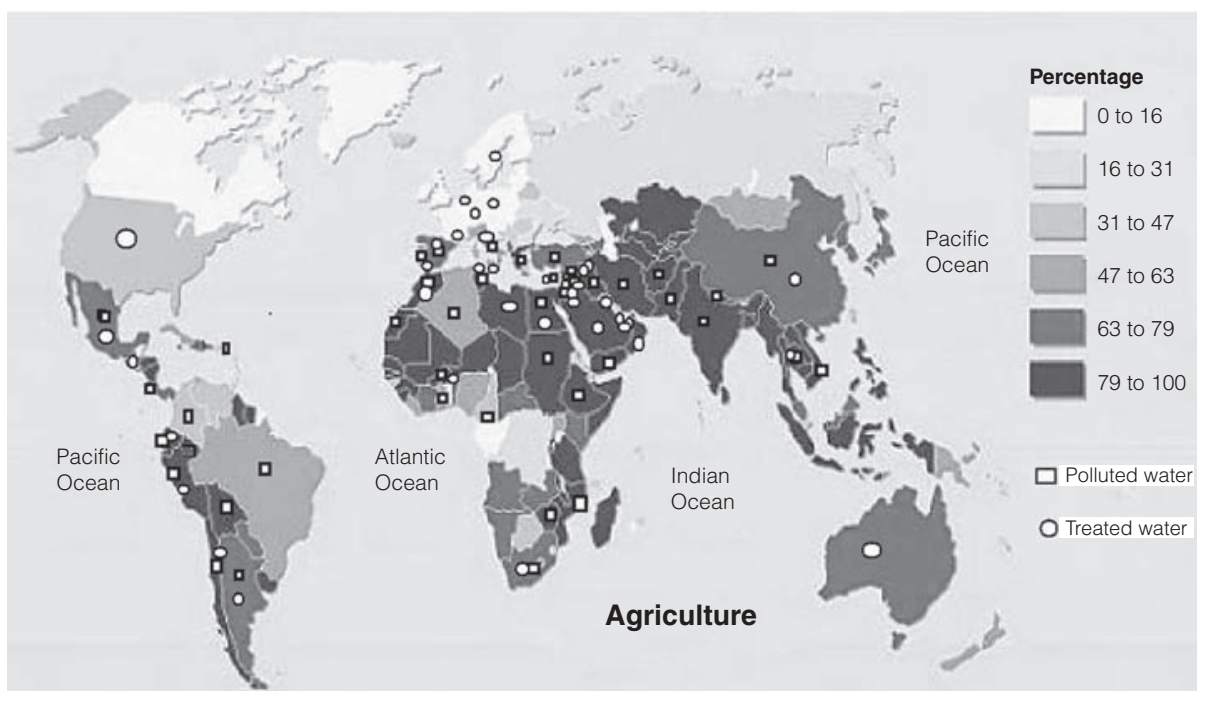

Figure 1.1 Freshwater withdrawals for agricultural use in the year 2000 and countries reporting the use of wastewater or polluted water for irrigation

Source: World Resources Institute (2000), adding information from Jiménez and Asano (2008); Keraita et al. (2008) and UNHSP (2008)

whilst mention will be made of reclaimed or recycled water, where relevant, the main thrust will be on non-treated wastewater.

\section{EXTENT OF THE USE OF WASTEWATER, EXCRETA AND SLUDGE}

In spite of the data limitations mentioned above, an attempt is made, in the following sections, to produce a broad picture of the extent of use of wastewater, sludge and excreta around the world using the best available information.

Table 1.1 Some characteristics of countries using wastewater for irrigation

\begin{tabular}{lccc}
\hline $\begin{array}{l}\text { Use of wastewater for } \\
\text { irrigation }\end{array}$ & $\begin{array}{c}\text { Total number of } \\
\text { countries }\end{array}$ & $\begin{array}{c}\text { GDP per capita for } \\
50 \% \text { of the countries } \\
\text { (in US\$) }\end{array}$ & $\begin{array}{c}\text { Sanitation coverage } \\
\text { for 50\% of the } \\
\text { countries (in \%) }\end{array}$ \\
\hline Untreated & 23 & $880-4800$ & $15-65$ \\
Treated and untreated & 20 & $1170-7800$ & $41-91$ \\
Treated & 20 & $4313-19800$ & $87-100$ \\
\hline
\end{tabular}




\section{Wastewater}

In the literature, there is no comprehensive global inventory of the extent of non-treated wastewater used for irrigation; actually, none exists even for treated wastewater. Based on information from the countries providing data on irrigated areas, it is estimated that more than 4-6 million hectares (ha) are irrigated with wastewater or polluted water (Jiménez and Asano, 2008; Keraita et al., 2008, UNHSP, 2008). A separate estimate indicates 20 million ha globally, an area that is nearly equivalent to 7 per cent of the total irrigated land in the world (WHO, 2006). In contrast, the area reported to be irrigated with treated wastewater amounts to only 10 per cent of this value. In practice, due to the under-reporting of areas irrigated with polluted water, the difference may be much higher. Two decades ago, WHO (1989) estimated that the area using raw wastewater or polluted water was 3 million ha; recent data suggest an area six times larger. It cannot be determined whether this difference refers to a de facto increase in the area or only in available data, but both might be the case, given the increasing amounts of wastewater generated as well as urban food needs.

The resulting agricultural activities are indeed most common in and around cities (Drechsel et al., 2006), but can also be seen in rural communities located downstream of where cities discharge, unless treatment or self-purification processes take place. Much of this use is not intentional and is the consequence of water sources being polluted due to poor sanitation and waste-disposal practices in cities. Raschid-Sally and Jayakody (2008) suggest from a survey across the developing world that wastewater without any significant treatment is used for irrigation purposes in four out of five cities.

In terms of volume of wastewater used for various purposes, the quantity varies considerably from one country to another. The majority of this is reported to be used in developing countries, where 75 per cent of the world's irrigated land is located (United Nations (UN), 2003), with a small amount, even if not expected, being used in some developed countries (Jiménez and Asano, 2008). In a new review integrating data from Jiménez and Asano (2008) and the UNHSP (2008), 46 countries report the use of polluted water for irrigation purposes (Figure 1.1). Table 1.1 shows a clear increase in GDP and the percentage of improved sanitation from countries using untreated to treated wastewater. Countries with middle income are those using both types of water, indicating a transition between unplanned and uncontrolled reuse to planned and controlled reuse. Countries using only treated water for irrigation purposes have sanitation coverage of at least 87 per cent.

Few studies have quantified the aggregate contribution of wastewater to food supply. In Pakistan, about 26 per cent of national vegetable production is irrigated with wastewater (Ensink et al., 2004), while in Hanoi, Vietnam, which is much wetter than Pakistan, about 80 per cent of vegetable production is from urban and peri-urban areas irrigated with diluted wastewater (Lai, 2002). Across major 
cities in West Africa, between 50 and 90 per cent of vegetables consumed by urban dwellers are produced within or close to the city (Drechsel et al., 2006) where much of the water used for irrigation is polluted.

The use of greywater exclusively has not been extensively documented, partly because it tends to be mixed together with blackwater. In cases where it is used as such, it is commonly an in-house practice, which makes it difficult to assess, but it is being popularized in the Middle East for irrigation purposes. In some States in the USA, greywater use is permitted for household irrigation and state legislation and guidelines exist. Australia, which has major scarcity problems, commissioned studies on greywater reuse but no comprehensive information is available. In countries where this is permitted, there are instances of greywater use for toilet flushing after treatment. Low- and middle-income countries such as India, Mali, Jordan, Palestine, South Africa, Nepal, Sri Lanka, Costa Rica and Malaysia are using greywater for gardening and irrigation of non-edible crops (such as fodder and olive trees) (Morel and Diener, 2006).

In most cities of sub-Saharan Africa, greywater is channelled into drains where it often gets mixed with stormwater, solid waste and excreta from open defecation before it enters natural water bodies. As these drains or streams are often used for irrigation, it is difficult to distinguish between greywater and wastewater use (Cornish and Lawrence, 2001; Drechsel et al., 2006; Qadir et al., 2007). A recent survey in two Ghanaian cities showed that greywater use for backyard irrigation is very low (International Water Management Institute (IWMI), 2008), despite the fact that greywater and blackwater have separate networks, and the proper use of greywater could be promoted. The situation can be different in drier areas where tap water is precious and natural water sources rare. Jordan is piloting projects with a view to upscaling greywater use as, for example, in the Jerash Refugee Camp, where greywater is separated and discharged from all houses into the environment through small ditches and open canals that serve farmers producing crops (WHOIDRC, 2006). India is also using partially treated greywater for kitchen-garden irrigation and sanitation (Godfrey et al., 2007) and it seems that this practice is beginning to be widely applied in several regions.

\section{Faecal sludge, excreta and biosolids}

The problem of faecal sludge management is compounded by the large number of on-site sanitation systems, such as latrines, unsewered public toilets or septic tanks, used by the majority of the population for disposal of blackwater in densely populated cities. Faecal sludge collected from on-site sanitation installations is sometimes transported to treatment ponds but is more often dumped in depressions, streams or the ocean, or reused untreated on farmland, discharged in lakes or fish ponds or disposed of within the household compound. Assuming a per capita faecal sludge production of 1 litre/day (Strauss et al., 1997), a truck-load 
of $5 \mathrm{~m}^{3}$ dumped indiscriminately is equivalent to 5000 open defecations (Koné et al., 2007a).

These practices represent a significant risk to public health and have a high disease impact on workers emptying the tanks and trucks, their families, the households living in the immediate area and on vulnerable populations in latrinebased cities (WHO, 2006). In Ghana, Mali and Benin, farmers are known to bribe septic truck drivers to dump the faecal matter in their fields. Fortunately, the practice poses little health risk to consumers where there is sufficient exposure to sun and a long dry season which result in pathogen die-off, or where the crops grown are cereals (Asare et al., 2003; Cofie et al., 2003, 2005). Systems where the faecal sludge is first dried and then mixed with solid waste for co-composting have been reported from experimental stations in Ghana and Nigeria. Settled sludge from sludge treatment ponds has also been used to 'blend' compost from solid waste, as observed in Accra, Ghana (Drechsel et al., 2004; Koné et al. 2007a).

Use of excreta is seldom made public, but is known to have been practised for centuries in Asia (WHO, 2006), in particular in China (UNHSP, 2008) and Vietnam (Jensen et al., 2005; Phuc et al., 2006) in both agriculture and aquaculture. In China, use of excreta in agriculture continues to be common and this practice has led to a strong economic linkage of urban dwellers and urban farmers. Thus, vegetables grown on excreta-conditioned soils yield higher sales prices. With increasing efforts to introduce urine-separating toilets, the first data on urine reuse has emerged. ${ }^{1}$

In both developed and developing countries, sludge disposal is an issue growing in line with the increase in the volume of wastewater treated. Historically, sewage sludge has been considered to be waste that is to be disposed of at the least possible cost (UNHSP, 2008). As a result, it has traditionally been dumped in landfills, holes, any unoccupied surface and drainage systems (Jiménez et al., 2004). However, faecal sludge, excreta and biosolids are increasingly being applied on land in low- and middle-income countries due to the high cost of modern landfills that meet all environmental requirements, the difficulty of finding suitable sites for landfills (even in developed countries) and the benefit of recycling plant nutrients and enhancing soil characteristics. Their main use worldwide (greater than 60 per cent) is to fertilize agricultural fields or green areas. This practice solves a problem for municipalities, helps farmers to decrease their organic and mineral fertilizer costs and preserves or improves soil fertility. Another important use of sludge is to improve degraded soils at mining sites, construction sites and other disturbed areas (UNHSP, 2008).

\section{DRIVERS OF WASTEWATER USE}

In developing countries, the limited financial and physical resources to treat water, the socio-economic situation and the context of urbanization create the conditions 
for unplanned and uncontrolled wastewater use. A study commissioned by the Comprehensive Assessment of Water Management in Agriculture showed that across 53 cities in the developing world the main drivers of wastewater use in irrigated agriculture are a combination of the following aspects (Raschid-Sally and Jayakody, 2008):

- limited capacities of cities to treat their wastewater, causing pollution of soils, water bodies and traditional irrigation water sources;

- lack of alternative (cheaper, similarly reliable, available or safer) water sources in the physical environment;

- urban food demand and market incentives favouring food production in the proximity of cities, where water sources are usually polluted.

In addition, Jiménez (2006) pointed to the influence of socio-economic factors at the household level, like poverty and low education in developing countries, where lack of job opportunities and a limited awareness for health risks coexist. In such circumstances, wastewater reuse can represent a promising opportunity for cash crop production or to improve food supply. Once wastewater reuse is in place and its advantages have been gauged by the population, it is difficult to alter behaviour especially if changes have an associated cost or are linked to historical water rights. This may be compounded by reduced availability of freshwater resources, be it for economic or physical reasons. The nutrient value of (raw) wastewater and sludge is inherently recognized by farmers, which is also a factor driving their use.

In contrast, in more developed countries, water reuse and recycling are increasingly seen as a means to respond to physical water scarcity (including climate change and drought management), water reallocations from agriculture to other uses and also as an economic response to costly inter-basin transfers. An additional factor influencing recycling is the stringent environmental standards, which make land application of wastewater and sludge both unavoidable and economically feasible.

Drivers of agricultural reuse of sludge and excreta are linked more to disposal issues than to the intention to reclaim components of them. However, many farmers consider them to be a valuable resource similar to farmyard manure. This beneficial use is increasingly gaining momentum, driven by the intention of closing nutrient loops to ensure that nutrients are returned to agricultural land to improve soil fertility. One of the main differences observed between the use of wastewater and that of sludge and excreta is a greater acceptance of wastewater use, as sludge and excreta have been historically considered, in most cultures, to be not only noxious but also an object of shame (UNHSP, 2008). 


\section{TYPOLOGY OF WATER USE}

Various authors have attempted to provide typologies for wastewater recycling and use (e.g. van der Hoek, 2004), but none of these has been taken up universally or been standardized. However, in describing wastewater reuse, the terms direct, indirect, planned and unplanned recur frequently. These are explained here with examples:

- Direct use of untreated wastewater refers to the use of raw wastewater from a sewage outlet, directly disposed of on land where it is used for crop production.

- Indirect use of untreated wastewater refers to the abstraction of usually diluted wastewater (or polluted stream water) for irrigation. This is common downstream of urban centres where treatment facilities are limited. Farmers might or might not be aware of the water-quality challenge.

- Direct use of treated wastewater refers to the use of reclaimed water that has been transported from the point of treatment or production to the point of use without an intervening discharge to waters.

- Planned water reuse refers to the conscious and controlled use of wastewater either raw (direct) or diluted (indirect). However, most indirect use happens without planning, at least initially, for using low quality water.

Direct use often takes place in dry climates where water sources are scarce. Treated, untreated or partially treated wastewater is used directly for irrigation without being mixed or diluted. Direct use of treated wastewater is most common as a planned process in developed countries including some larger parts of the Middle East and North African region, but can also take place unplanned, for example in dry seasons, when streams only carry wastewater, as is the case for the Musi River in Hyderabad, India.

However, the use of diluted wastewater for irrigation (indirect use) is significantly more frequent than direct use and occurs even more in wetter climates. In this situation, untreated or partially/insufficiently treated wastewater from urban areas is discharged into drains, small streams and other tributaries of larger water bodies where it is usually mixed with stormwater and freshwater, resulting in diluted wastewater (or polluted surface water). It is then used by farmers, most of whom are traditional users of these water sources. Lack of adequate sanitation and wastedisposal infrastructure in cities is one of the direct causes of such pollution and use (Jiménez and Asano, 2008, Raschid-Sally and Jayakody, 2008).

This situation is not limited to low-income countries that have no capacity to collect and treat wastewater comprehensively, but occurs also in fast-growing economies like China, Brazil, and some countries of the Middle East and North Africa region. For example, despite massive investments in wastewater treatment, 
the city of Beijing is only able to treat about half of the wastewater generated and untreated wastewater is discharged into waterways used downstream by farmers (Yang and Abbaspour, 2007). Also, in Lebanon and Palestine most of the wastewater collected from sewered localities is discharged into nearby rivers, wadis, and the sea, and on open land from where it infiltrates the ground with little or no treatment (Post et al., 2006). In spite of strict European Union (EU) regulations, untreated wastewater is discharged into rivers which are used for irrigation in some countries such as Spain, Italy and Portugal, especially in summer when there is little or no river flow (Juanico and Salgot, 2008). However, this practice is being reduced due to efforts made by countries to increase the level of wastewater treatment to meet EU legislation. In Turkey, an enormous amount of domestic wastewater is discharged into rivers and used for irrigation because of insufficient sewerage facilities and lack of satisfactory treatment (Juanico et al., 2008).

In some areas, irrigation infrastructure originally built to transport freshwater, surface or groundwater, is now used for wastewater during certain periods. Wastewater is pumped into irrigation canals to supplement fresh irrigation water. For instance, in Vietnam, wastewater from Hanoi and other cities along the Red River Delta is pumped into irrigation canals at certain times of the year to supplement irrigation water (Trang et al., 2007a and b). However, at the tail end of irrigation systems or throughout in the dry season, wastewater may be the only water flowing in the canals in areas such as Haroonabad in Pakistan and Hyderabad in India (Ensink et al., 2004; Ensink, 2006).

In Jordan, the As-Samra wastewater treatment plant mainly treats the domestic wastewater of the capital Amman. On its course to the Jordan Valley, the reclaimed water is mixed with surface run-off from wadis before it is temporarily stored in the country's largest reservoir, the King Talal Reservoir (KTR) (which has a storage capacity of 75 million cubic metres). The detention time of the water in the reservoir, which used to be about ten months, has been reduced to a few months with the increase of the wastewater flow. About $20 \mathrm{~km}$ downstream from the KTR outlet, Zarqa Carriers divert part of the KTR water directly to fields in the Jordan Valley. The rest of the reclaimed water is finally released into the King Abdullah Canal which brings freshwater in the north to the Jordan Valley.

\section{ADVANTAGES AND DISADVANTAGES OF REUSING WASTEWATER, SLUDGE, AND EXCRETA}

While the drivers for the use of wastewater, sludge and excreta in agriculture differ between regions, their use - be it directly, indirectly, diluted or not - has a number of advantages alongside the well-known risks (WHO, 1989, 2006; Scott et al., 2004). 


\section{Advantages}

As a consequence of the high global food demand, it is not surprising that, worldwide, the biggest user of wastewater (treated or not) is agriculture (Jiménez and Asano, 2008). An important factor which makes wastewater valuable is that it is a reliable source of water, as it is available all year round, unlike pluvial precipitation or seasonal streams. Consequently, it permits higher crop yields, year-round production, and increases the range of crops that can be irrigated, particularly in (but not limited to) arid and semi-arid areas (Keraita et al., 2008). Studies conducted in Hubli-Dharwad showed that wastewater allowed farming to be done in the dry season when farmers could sell their produce at three to five times the kharif (monsoon) season prices (Huibers et al., 2004). Wastewater reliability also allows for multiple cultivation cycles and flexibility of crops planted (Raschid-Sally et al., 2005). Similar situations have been reported for Haroonabad, Pakistan; Accra, Ghana; and Dakar, Senegal (Gaye and Niang, 2002; van der Hoek et al., 2002; Koottatep et al., 2006). The increased productivity and related income/food supply gains allow farmers a more reliable livelihood with indirect benefits of using the income for education and improving health conditions.

Where vegetables are the main commodity produced with wastewater, there can be a significant aggregate benefit for the society in terms of a more balanced diet. In the case of Accra, for example, more than 200,000 people eat vegetables produced with wastewater every day (Amoah et al., 2007). On the other hand, this is also the group potentially at risk as the possible adverse health effects to farmers and consumers are well established (WHO, 2006).

As part of the urban food-production systems, urban livestock contributes to cities' food security by providing meat and dairy products (Bonfoh et al., 2003; Wolf et al., 2003). In semi-arid countries, livestock production relies mainly on natural pasture, which is often limited or decreasing due to low precipitation. In Sahelian countries (i.e. Burkina Faso, Mali, Senegal), forage biodiversity has decreased over time and plant species with lower nutritive value and palatability are becoming predominant (Bonfoh et al., 2003 and 2006; Food and Agriculture Organization of the United Nations (FAO), 2006; Sanon et al., 2007; Toutain et al., 2006). At the same time, however, the demand for dairy in cities is increasing with urbanization and changing diets. For example in Asian countries, the demand for dairy products is growing by a factor of 3.5 per year (Moran, 2005). Reusing wastewater or faecal sludge for fodder production appears an important and comparatively low-risk avenue which can contribute to enhancing the resilience to climate changes and food insecurity especially of small and middle-sized cities in developing countries (Koné, in press).

Another well-established advantage of wastewater and sludge reuse is their nutrient content. Even when treated, wastewater recycles organic matter and a larger diversity of nutrients than any commercial fertilizer can provide. Biosolids, sludge and excreta in particular, provide numerous micronutrients such as cobalt, copper, iron, manganese, molybdenum and zinc, which are essential for optimal 
plant growth. It is estimated that 1000 cubic metres of municipal wastewater used to irrigate one hectare can contribute $16-62 \mathrm{~kg}$ total nitrogen, $4-24 \mathrm{~kg}$ phosphorus, 2-69kg potassium, 18-208kg calcium, 9-110kg magnesium, and $27-182 \mathrm{~kg}$ sodium (Qadir et al., 2007). It therefore can reduce the demand for chemical fertilizers especially where the wastewater is not diluted, i.e. make crop nutrients more accessible to poor farmers. In the light of the global phosphorus crisis, excreta and wastewater can be critical sources of phosphorus (Rosemarin, 2004). On the other hand, excessive concentrations of nitrogen in wastewater can lead to over-fertilization and cause excessive vegetative growth, delayed or uneven crop maturity and reduced quality (Jiménez, 2006; Qadir et al., 2007). Excessive concentrations of some trace elements may also cause plant toxicity and sometimes become a health risk for crop consumers.

Few studies have quantified the economic gains from nutrients in wastewater under actual field conditions. In Guanajuato, Mexico, the estimated saving arising from using wastewater to supply the required nitrogen and phosphorus for crops was US\$135 per hectare (Keraita et al., 2008). A study comparing vegetable production using freshwater and untreated wastewater in Haroonabad, Pakistan, found that the gross margins were significantly higher for wastewater (US\$150 per hectare), because farmers spent less on chemical fertilizer and achieved higher yields (van der Hoek et al., 2002).

In a cost-benefit analysis of greywater reuse systems constructed in residential schools in India, the internal and external benefits far outweighed the costs (Godfrey et al., 2009). Although studies conducted to quantify economic returns are still few and lack a uniform methodological approach, they consistently report significant gains among farmers with access to wastewater. The annual income reported in such studies performed in India, Ghana, Senegal, Kenya and Mexico varied from US $\$ 420$ to $\$ 2800$ per hectare per year (Keraita et al., 2008). According to studies in Ghana, the greatest factor influencing farmers' profits is not so much the yield obtained, but the ability to produce crops that are in high demand and low supply, at the right time, the result being that they can be consistently sold at above average prices (Cornish et al., 2001). The profitability of the business is also reflected in farmers' decisions to pay more for (especially nutrient-rich) wastewater than normal water. In the Mezquital Valley, Mexico, the availability of wastewater instead of freshwater as irrigation water caused land rents to increase from US $\$ 170$ to \$350-950 per year (Jiménez, 2005). In Quetta, Pakistan, farmers paid 2.5 times more for wastewater than for freshwater (Ensink et al., 2004).

While farmers and their families are direct beneficiaries, there are also indirect beneficiaries along the supply chain including farm labourers, transporters, vendors, processors, input suppliers and consumers (Buechler et al., 2002). With low investments and quick returns, this practice is lucrative and enables many farmers to leap over the poverty line (Danso et al., 2002). In many West African countries, it is especially attractive to poor migrants looking for jobs in the city (Faruqui et al., 2004). 


\section{BOX 1.2 DISEASES COMMONLY ASSOCIATED WITH WASTEWATER AND EXCRETA}

The most common diseases associated with wastewater and excreta are the diarrheic ones. Examples include several kinds of helminthiases that are caused by intestinal infestation of parasitic worms. Helminthiases are common where poverty and poor sanitary conditions prevail; under these conditions they can affect up to 90 per cent of the population (Bratton and Nesse, 1993). Ascariasis (produced by Ascaris worms) is the most common one and is endemic in Africa, Latin America, and the Far East. It is estimated that 133 million people suffer from high-intensity ascariasis infections, which often lead to severe consequences, such as cognitive impairment, severe dysentery or anaemia. Even though helminthiases have a low mortality rate (for ascariasis nearly 10,000 persons per year), most of the people affected are children under 15 years old with problems of faltering growth and/or impaired fitness. Approximately 1.5 million of these children never attain expected growth, even if treated (Silva et al., 1997). Another common helminthiasis is Schistosomiasis that affects approximately 246 million people worldwide (United Nations, 2003). It causes tens of thousands of deaths every year, mainly in sub-Saharan Africa. It is strongly related to unsanitary excreta disposal and the absence of nearby sources of safe water.

Another important disease is cholera, caused by bacteria named Vibrio cholerae. These bacteria cause not only epidemics but are responsible for several pandemics. Cholera is strongly related to the use of polluted water for irrigation or to unsafe disposal of sludge and excreta. Major risks occur where there are large concentrations of people and hygiene is poor (as in refugee camps and urban slums).

Other diarrheic diseases related to unsafe agricultural practices are salmonellosis, typhoid, shigellosis, gastric ulcers (caused by Helicobacter pylori), giardiasis and amoebiasis (Blumenthal and Peasey, 2002). In addition, skin diseases associated with contact with untreated water have been reported. Nail problems (koilonychias) characterized by spoon-formed nails have also been reported and are associated with the anaemia produced by hookworm infections which cause iron deficiency (van der Hoek et al., 2002). However, it must be kept in mind that in developing countries with various disease exposure pathways, the comparative risk contribution from wastewater irrigation and contaminated crops has never been comprehensively studied. Quantitative microbial risk assessment (QMRA) methodologies can and should be used effectively for this purpose, in order to have a realistic perspective of the situation.

The land application of wastewater, sludge and excreta for agricultural use constitutes a low-cost disposal method and a land-treatment system that uses the soil to attenuate contaminants. If carried out under controlled conditions, it can also be safe. Wastewater use can also recharge aquifers through infiltration or reduce the impact on surface-water bodies, as wastewater is 'treated' in the vadose before reaching them (Jiménez, 2006). Several wastewater constituents are subject to processes that remove them or significantly reduce their concentration. Reduced costs to society are also noteworthy, in view of reducing the use of fossil fuels to produce fertilizer. 


\section{Disadvantages}

Among the disadvantages of using untreated or partially treated wastewater, sludge or excreta, the most obvious are the health risks from pathogens. These have been discussed extensively elsewhere (WHO, 2006) and are also the subject of several chapters in this book. Some references will be provided here in order to give an idea of the magnitude of the problem. Firstly, it should be stated that diseases are linked to the nature of the pathogen in the wastewater and thus vary locally following the local public-health pattern. Secondly, risks are not limited to farmers, but can be observed in four groups: agricultural workers and their families; crop handlers; consumers of crops or meat and milk coming from cattle grazing on polluted fields; and those living on or near the areas where wastewater, sludge or excreta is used. Within these groups the most vulnerable sections of the population are children and the elderly. Thirdly, observed responses may vary considerably between developing and developed countries. This is because pathogen distributions and concentrations, to which these groups are exposed, are very different, as are the living conditions and the level of resistance to disease between developing and developed countries (Jiménez, 2007; Jiménez and Wang, 2006). Furthermore, the statistics on food safety are unreliable because laboratory standards are so low in most developing countries.

Pathogens contaminate crops mainly via direct contact, though some cases of uptake by plants have been recorded (Hamilton et al., 2007). Beside pathogens, wastewater and sludge can also be a source of high levels of heavy metals and organic toxic compounds (Abaidoo et al., 2009; Hamilton et al., 2007). Contamination can occur, in the case of metals and some organic chemicals, through absorption from the soil, which strongly depends on the location (possible contamination sources), the environmental conditions (particularly the soil), bio-availability (in the case of some contaminants), type of plant and agricultural practices (quantity of water applied and irrigation method) (Jiménez, 2006).

There is relatively good knowledge concerning the allowable amounts of heavy metals that crops and soil can be exposed to when wastewater, sludge or biosolids are applied to soil (Page and Chang, 1994; UNHSP, 2008; WHO, 2006). Moreover, for both developed and developing countries, the content of heavy metals in wastewater, excreta and sludge from domestic sources is generally low enough to allow their use for crop fertilization (Jiménez and Wang, 2006; UNHSP, 2008; WHO, 2006). However, there are always cases where care has to be taken, for example, close to tanneries or mining areas (Abaidoo et al., 2009). The risk from organic components derived via wastewater is in general much lower than via direct pesticide application. In comparison with pathogenic health risks, pesticide levels on vegetables, even if elevated, were considered to be of secondary importance in the context of a developing country (Amoah et al., 2006).

As described above, the use of wastewater, biosolids and excreta implies benefits but also risks. Frequently, experts recommend simply banning this unsafe practice and 'properly' treating wastewater, sludge and excreta. Such recommendations, 
besides being nearly impossible to implement in most developing countries for both economic and social reasons, would also result in the removal of components from these 'waste' products that are not acting as pollutants but, conversely, are beneficial. Therefore, in practice, there has to be a trade-off between the advantages and disadvantages and the best solution for each situation should be sought, even if this is considered unconventional, especially from a developed country perspective. From a technical point of view, the solution will basically consist of finding a way to supply soils and crops with water, nutrients and organic matter. This should take advantage of the assimilation capacity of the soil, so that pathogens or heavy metals do not cause harm, while putting in place additional measures to deliver safe food to consumers. These and other alternative options for health-risk reduction are supported by the Guidelines of WHO (2006) where conventional wastewater treatment fails for whatever reason (see Chapters 10 to 12 of this book).

\section{OFFICIAL PERCEPTION AND POLICY GUIDANCE}

\section{Wastewater and excreta}

Policies to control the unplanned reuse of wastewater where it is an ongoing practice are not only hard to implement but are even difficult to develop (Drechsel et al., 2002) because governments are faced with the trade-off between publichealth protection and the ethical question of whether to prevent wastewater farmers from cultivating with the only source of water that is accessible to them (Jiménez and Garduño, 2001). The WHO, to assist in this decision-making process, has in recent years been giving consideration both to the limitations faced by developing countries in providing sufficient wastewater treatment to meet water-quality standards and the increasingly important livelihood dimension of wastewater use. This is reflected in the 2006 Guidelines.

If a government concludes that the practice must be stopped, then it has to put in place a complex process for control, with few successful examples in practice. In almost all countries legislation exists, dating back several years or decades and referring directly or indirectly to the use of polluted water or wastewater for irrigation, which is always forbidden. Many countries have irrigation water-quality guidelines, but they do not always consider microbiological standards, and where wastewater use is permitted, the legislation requires that certain quality conditions are met. Such conditions usually follow the previous WHO Guidelines (1989) which recommended water-quality thresholds. (This approach has now been revised: see the following chapter.) Such regulations are not followed in practice for the many reasons mentioned above. A further factor is that wastewater irrigation usually takes place outside the officially recognized formal irrigation sector. As a result, most governments ignore the situation or have no other means than to adopt a laissez-faire attitude (Drechsel et al., 2006). 
Joint efforts by WHO, FAO and United Nations Environment Programme (UNEP) to respond to this global situation, and to encourage resource recovery, resulted in an enforceable and achievable regulatory framework to support worldwide the reuse of wastewater, greywater and excreta in agriculture and aquaculture (Jiménez and Asano, 2008; WHO, 2006). These new Guidelines build on previous ones but are in their 2006 version much more supportive of the difficult sanitation conditions in most developing countries and have suggested a multiplebarrier approach for the long-term achievement of a universal health-based target. Furthermore, WHO suggests local adaptation of the Guidelines with incremental achievements towards this target. This flexibility means that authorities require support to understand and apply the new approach. The previous WHO Guidelines (1989) are often considered more straightforward, especially for countries that already have comprehensive wastewater collection and treatment in place.

The resulting bias towards countries at the lower part of the sanitation ladder caused discomfort among those countries further up which have few problems in enforcing and monitoring crop or water-quality thresholds. These countries prefer to use, for example, standards similar to the California Title 22 (State of California, 2001). Such fixed standards are indeed most useful where they can actually be met by treatment, and wastewater use is a planned and controlled activity. However, they are difficult to apply where treatment is rudimentary or lacking and when thousands of farmers already use polluted water sources because they have no alternative. Here, different strategies for health-risk reduction are needed. Similar regulations based on local needs and capabilities had been developed before the 2006 WHO Guidelines were released, e.g. in Australia (AATSE, 2004) and in Mexico in 1996 (Jiménez, 2005). The advantage of the WHO Guidelines is that all the developing countries that have ignored previous guidelines, because the water-quality thresholds were too high, are now challenged to control the health risks as far as possible, rather than continuing to disregard the problem. The same applies to excreta management which the WHO (2006) is also addressing.

\section{Treated and untreated sludge}

Sludge management is mostly an issue for developed countries where wastewater treatment facilities allow sludge generation, separation, storage, transport and reuse. Considerable experience concerning the development of policies and regulations to promote the beneficial use of municipal sludge and biosolids in soil exists in the EU and the USA. These regions have comprehensively analysed the risks and benefits of the different use and disposal options. Many other countries have built their understanding and policies from this foundation of knowledge and experience, but integrate local needs and conditions into their policies, laws and regulations.

In general, the USA has adopted the concept of risk assessment in their environmental regulations contained in the 40 CFR Part 503 sludge regulation 
dating from the early 1990s. The approach takes maximum advantage of the soil's capacity to assimilate, attenuate and detoxify pollutants. Land application guidelines based on this approach set the maximum permissible pollutant loading and provide users with the flexibility to develop suitable management practices for using sewage sludge (Chang et al., 2002). In contrast, the EU has adopted a precautionary or a no-net-degradation approach (UNHSP, 2008). This approach prevents pollutant accumulation into biosolids-receiving soils. As a result of this, the EU is well ahead of the USA in researching and phasing out chemicals of concern in personal care and commercial products, resulting in more costly control programmes. Both approaches address pathogen reduction, the potential for accumulation of persistent pollutants in soils (heavy metals and persistent chemicals) and the application of appropriate amounts of nutrients. One notable difference is that the EU Directive has stringent upper limits for pollutants and generally limits rates of applications of biosolids to lower amounts than are allowed in the USA. The cost of implementation of the Directive is also higher, as wastewater treatment plants need to employ advanced wastewater treatment technologies to minimize the pollutant levels in the reclaimed wastewater and sewage sludge.

Regulatory structures in other countries that may not have the same level of resources available for wastewater sludge management are less precautionary. Balancing the need for strong regulations and enforcement with what is practical and achievable is the challenge. Snyman (2008), for example, has pointed out that in South Africa an initial set of biosolids management regulations that were consistent with some of the stricter regulations in Europe made management of wastewater sludge nearly impossible. Newer, more appropriate regulations are now helping move the country's wastewater sludge management programmes towards higher levels of recycling and greater sustainability.

Examples of sludge management policies implemented in developing countries are still rare as the existence of properly functioning wastewater treatment plants is still an evolving phenomenon. One notable example occurs in the state of Paraná in Brazil where practical, successful, full-scale programmes can be found (Andreoli et al., 2008). In Tunisia, standards have been established for maximum allowable concentrations of chemical and biological components in soil and sewage sludge. Pollutant concentration limits for land application of sewage sludge were derived from the existing regulations, while specific management practices for land application and disposal of sewage sludge have been included in the national standards.

\section{Perspectives AND CONClusions}

With an increasing world population and improved living standards, domestic water use will increase and so will the production of wastewater, excreta and biosolids. Similarly, the share of the urban population using on-site sanitation 
(a)

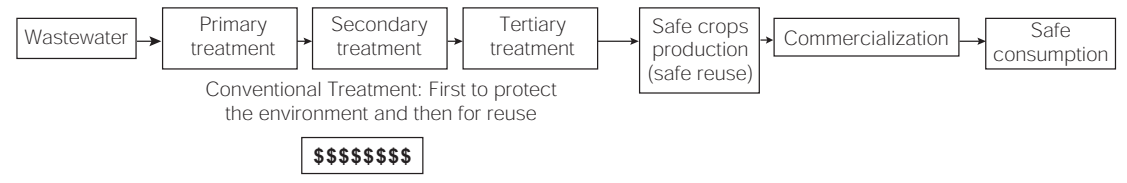

(b)

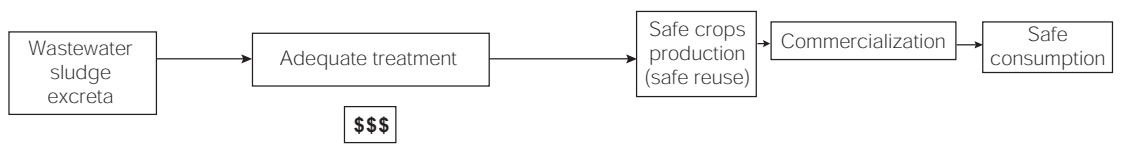

(c)

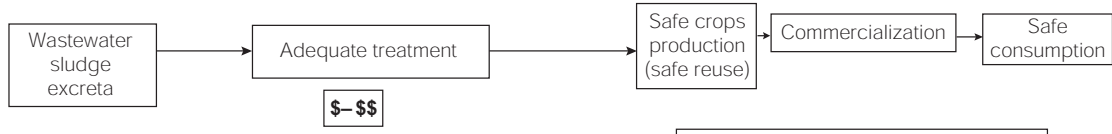

Additional options of interventions

$\$ \$$

Figure 1.2 Options to deal with the reuse of wastewater for agricultural purposes

systems (currently 40 per cent or 1.1 billion world urban dwellers) will increase with efforts to improve sanitation coverage. Hence, a huge quantity of faecal sludge will have to be dealt with in the future (Koné et al., 2007b).

Simultaneously, there are many regions facing severe freshwater shortages which are responding increasingly with unplanned or planned wastewater use. Water scarcity will thus continue to be a key driver for recycling wastewater next to poor sanitation and widespread water pollution. Reuse will be supported by economic and environmental perspectives to substitute for some uses that do not need potable water quality and will contribute to nutrient recovery (Mekala et al., 2007). Whilst planned reuse (of treated wastewater) will be the norm in countries that can afford treatment, the vast majority of low-income countries are, however, likely to continue to use non- or only partially treated wastewater, as long as sanitation and waste disposal do not keep pace with population growth in cities.

In the case of wastewater, there are three possible scenarios that future policy needs to address:

- Continue to promote wastewater reuse in the traditional way (Figure 1.2a), using conventional treatment methods developed first to protect the environment and then to reuse water. As a result, norms are very stringent and treatment methods are based on adding steps to conventional wastewater treatment systems to further improve quality. This will lead to higher costs, more fragile systems with probably lower viability in developing countries and the removal 
of nutrients from water which does not favour agricultural reuse (Jiménez and Garduño, 2001).

- Look for appropriate treatment alternatives (Figure 1.2b) that adequately target health protection and enhance reclamation of water and nutrients (Jiménez and Garduño, 2001; Koné, in press). For example, linking wastewater or faecal sludge treatment to forage production can generate additional income for operation and maintenance and support local dairy production systems. In this option, as the treatment of wastewater is designed from the outset to reuse wastewater, it can be performed at a lower cost than the first option, but differs from the third option in that health risks should be controlled solely with treatment; no other interventions are considered.

- Apply an integrated approach (Figure 1.2c) combining a locally adequate treatment process, which in combination with ('non-treatment') interventions applied at different entry points along the production and consumption chain, will achieve the health target required.

The last two options are similar, varying only in the type of additional intervention methods considered and can also be applied to sludge and excreta. The third option is in line with the current WHO Guidelines (2006).

With regard to excreta management, a more sensitive approach is needed which respects cultural perceptions. The long-term goal is to move from the ignorance of what happens to people's wastewater and excreta after they are discarded, towards educating people on what is done - and what could be done - with their waste as a valuable resource (UNHSP, 2008).

The global fertilizer and energy crises call for the development of alternative solutions for producing affordable nutrients which can sustain agricultural food production. A new paradigm in waste processing is needed. Population growth, urbanization and improved quality of life are accompanied by an increase in demand for food and water, leading to the generation of large concentrations of waste products originating from urban centres. In addition, there are the expected impacts of climate change, which will reduce water availability, and a growing awareness of environmental water needs.

Under these conditions, resource recovery of biosolids, water and nutrients becomes essential. The most appropriate options for water and excreta reuse are offered by the agricultural sector which uses on average around 80 per cent of total water consumption in developing countries; moreover, agriculture accepts a lower water quality compared to other uses (Jiménez and Garduño, 2001). In fact, water and nutrient recovery is happening extensively already but the practice at present is not free from risks. To move forward, a strategy that accommodates the needs of the users while fulfilling the public health and environment requirements is essential. This strategy should be developed locally, based on local options and needs, and can contribute to financing treatment facilities. A related concept (Design for Service) is described in Chapter 15. 
In the case of sludge, biosolids and excreta, it is expected that the decreasing availability especially of natural phosphorous reserves will increasingly shift the attention to ecological sanitation in its broad sense and the need for nutrient recovery.

There is clearly an opportunity for urban planners and policy-makers to reinvent the role of excreta and wastewater treatment infrastructure by linking them to city development and food security agendas. It is a considerable matter of concern that the present rate of economic growth and the probable impact of climate change are already overshooting the carrying capacity of the earth's ecosystems to produce the required resources and to absorb the pollution caused by human activities. The impact of the expected doubling of the human population by the middle of the next century, most of which will take place in developing countries, calls for the definition of a clear environmental sustainability strategy for renewable resources management.

Linking urban faecal sludge and wastewater treatment and management infrastructure to the agenda of food production and food security can draw financial resources for building infrastructure and securing operation and maintenance costs, as city planners and utilities might see the direct economic benefits. It is also an opportunity to close the nutrient and water loops through resource-oriented urban excreta and wastewater management.

\section{NoTeS}

1 See http://conference2005.ecosan.org.

2 The hectare base is used for standardization; farmers' fields might be much smaller.

\section{REFERENCES}

AATSE-Australian Academy of Technological Sciences and Engineering (2004) Water Recycling in Australia, AATSE, Victoria, Australia

Abaidoo, R., Keraita, B., Drechsel, P., Dissanayake, P. and Maxwell, A. (2009) 'Soil and crop contamination through wastewater irrigation and options for risk reduction in developing countries', in P. Dion (ed) Soil Biology and Agriculture in the Tropics, Springer Verlag, Heidelberg

Amoah, P., Drechsel, P., Abaidoo, R. C. and Henseler, M. (2007) 'Irrigated urban vegetable production in Ghana: Microbiological contamination in farms and markets and associated consumer risk groups', Journal of Water and Health, vol 5, no 3, pp455-66

Amoah, P., Drechsel, P., Abaidoo, R. C. and Ntow, W. J. (2006) 'Pesticide and pathogen contamination of vegetables in Ghana's urban markets', Archives of Environmental Contamination and Toxicology, vol 50, no 1, pp1-6

Andreoli, C., Garbossa, L., Lupatini, G. and Pegorini, S. (2008) 'A Brazilian approach in United Nations Human Settlements Programme', in R. LeBlanc, P. Matthews and P. Roland (eds) Global Atlas of Excreta, Wastewater Sludge, and Biosolids Management: 
Moving Forward the Sustainable and Welcome Uses of a Global Resource, UN-Habitat, Nairobi, pp131-46

Asano, T., Burton, H., Leverenz, H., Tsuchihashi, R. and Tchobanoglous, G. (2007) Water Reuse: Issues, Technologies, and Applications, McGraw-Hill Professional, New York, p1570

Asare, I., Kranjac-Berisavljevic, G. and Cofie, O. (2003) 'Faecal sludge application for agriculture in Tamale', Urban Agriculture Magazine, vol 10, pp31-3

Blumenthal, U. J. and Peasey, A. (2002) 'Critical review of epidemiological evidence of the health effects of wastewater and excreta use in agriculture', unpublished document prepared for World Health Organization, Geneva, www.who.int/water_sanitation_ health/wastewater/whocriticalrev.pdf

Bonfoh, B., Ankers, P., Sall, A., Diabaté, M., Tembely, S., Farah, Z., Alfaroukh, O. I. and Zinsstag, J. (2006) 'Operational plan for small scale milk producers in peri-urban of Bamako (Mali)', Journal of Sahelian Studies and Research, vol 12, nos 7-25

Bonfoh, B., Sall, A., Diabaté, M., Diarra, A., Netoyo, L., Mbaye, Y., Simbé, C. F., Alfaroukh, O. I., Farah, Z. and Zinsstag, J. (2003) 'Viabilité technico-économique du système extensif de production et de collecte de lait à Bamako', Revue Etudes et Recherches Sahéliennes, vols 8-9, pp173-84

Bratton, R. and Nesse, R. (1993) 'Ascariasis: An infection to watch for in immigrants', Postgraduate Medicine, vol 93, pp171-8

Buechler, S., Devi, G. and Raschid-Sally, L. (2002) 'Livelihoods and wastewater irrigated agriculture along the Musi River in Hyderabad City, Andhra Pradesh, India', Urban Agriculture Magazine, vol 8, pp14-17

Chang, A. C., Pan, G., Page, A. L. and Asano, T. (2002) 'Developing human healthrelated chemical guidelines for reclaimed wastewater and sewage sludge applications in agriculture', report submitted to World Health Organization, Geneva

Cofie, O., Kranjac-Berisavljevic, G., Drechsel, P. (2005) 'The use of human waste for peri-agriculture in northern Ghana', Renewable Agriculture and Food Systems, vol 20, no 2, pp73-80

Cofie, O., Strauss, M., Montangero, A., Zurbrugg, C. and Drescher, S. (2003) 'Cocomposting of faecal sludge and municipal organic waste for urban and peri-urban agriculture in Kumasi, Ghana', Final Project Report submitted to PSEau, IWMI, Ghana, p123

Cornish, G. and Lawrence, P. (2001) 'Informal irrigation in peri-urban areas: A summary of findings and recommendations', Report OD/TN 144, Nov 2001, HR Wallingford Ltd, Wallingford, UK

Danso, G., Drechsel, P., Wiafe-Antwi, T. and Gyiele, L. (2002) 'Income of farming systems around Kumasi', Urban Agriculture Magazine, vol 7, pp5-6

Drechsel, P., Blumenthal, U. J. and Keraita, B. (2002) Balancing health and livelihoods: Adjusting wastewater irrigation guidelines for resource-poor countries', Urban Agriculture Magazine, vol 8, pp7-9

Drechsel, P., Cofie, O., Fink, M., Danso, G., Zakari, F. M. and Vasquez, R. (2004) 'Closing the rural-urban nutrient cycle. options for municipal waste composting in Ghana', Final Scientific Report submitted to IDRC (project 100376), IWMI, Ghana

Drechsel, P., Graefe, S., Sonou, M. and Cofie, O. (2006) Informal irrigation in urban West Africa: An overview', Research Report 102, International Water Management Institute, Colombo, Sri Lanka 
Ensink, J. (2006) 'Water quality and the risk of hookworm infection in Pakistani and Indian sewage farmers', PhD thesis, London School of Hygiene and Tropical Medicine, University of London, London

Ensink, J., Mahmood, T., van der Hoek, W., Raschid-Sally, L. and Amerasinghe, F. (2004) 'A nation-wide assessment of wastewater use in Pakistan: An obscure activity or a vitally important one?', Water Policy, vol 6, pp197-206

FAO (2006) 'Country pasture/forage resource profiles - Burkina Faso', FAO, Rome, www.fao.org

Faruqui, N., Niang, S. and Redwood, M. (2004) 'Untreated wastewater reuse in market gardens: A case study of Dakar, Senegal', in C. Scott, N. Faruqui and L. RaschidSally (eds) Wastewater Use in Irrigated Agriculture: Confronting the Livelihood and Environmental Realities, CABI Publishing, Wallingford, UK, pp113-25

Gaye, M. and Niang, S. (2002) Epuration des eaux usées et l'agriculture urbaine, Etudes et Recherches, ENDA-TM, Dakar, Senegal

Godfrey, S., Labhasetwar, P., Swami, A., Wate, S. R., Parihar, G. and Dwivedi, H. (2007) 'Water safety plans for grey water in tribal schools', Water Lines, vol 5, no 3, pp8-10

Godfrey, S., Labhasetwar, P. and Wate, S. (2009) 'Greywater reuse in residential schools in Madhya Pradesh India - a case study of cost benefit analysis', Resources, Conservation and Recycling, vol 53, pp287-93

Hamilton, A. J., Stagnitti, F., Xiong, X., Kreidl, S. L., Benke, K. K. and Maher, P. (2007) 'Wastewater irrigation: The state of play', Vadose Zone Journal, vol 6, no 4, pp 82340

Hoek, W. van der (2004) 'A framework for a global assessment of the extent of wastewater irrigation: The need for a common wastewater typology', in C. A. Scott, N. I. Faruqui and L. Raschid-Sally (eds) Wastewater Use in Irrigated Agriculture: Confronting the Livelihood and Environmental Realities, CABI Publishing, Wallingford, UK, pp11-24

Hoek, W. van der, Ul Hassan, M., Ensink, J., Feenstra, S., Raschid-Sally, L. and Munir, S. (2002) 'Urban wastewater: A valuable resource for agriculture', International Water Management Institute Research Report, vol 63, Colombo

Huibers, F., Moscoso, O., Duran, A. and van Lier, J. (2004) 'The use of wastewater in Cochobamba, Bolivia: A degrading environment', in C. Scott, N. Faruqui and L. Raschid-Sally (eds) Wastewater Use in Irrigated Agriculture: Confronting the Livelihood and Environmental Realities, CABI Publishing, Wallingford, UK, pp135-44

IWMI (2008) 'Household survey on the role of backyard gardens for food security and food supply in Kumasi and Accra, Ghana', report, International Water Management Institute, Africa office, Accra

Jensen, P. K., Phuc, P. D., Dalsgaard, A. and Konradsen, F. (2005) 'Successful sanitation promotion must recognize the use of latrine wastes in agriculture - the example of Vietnam', WHO Bulletin, vol 83, pp273-4

Jiménez, B. (2005) 'Treatment technology and standards for agricultural wastewater reuse', Irrigation and Drainage, vol 54, no 1, pp 22-33

Jiménez, B. (2006) 'Irrigation in developing countries using wastewater', International Review for Environmental Strategies, vol 6, no 2, pp229-50

Jiménez, B. (2007) 'Helminth ova control in sludge: A review', Water Science and Technology, vol 56, no 9, pp147-55 
Jiménez, B. and Asano, T. (2008) 'Water reclamation and reuse around the world', in B. Jiménez and T. Asano (eds) Water Reuse: An International Survey of Current Practice, Issues and Needs, IWA Publishing, London, p648

Jiménez, B., Barrios, J., Mendez, J. and Diaz, J. (2004) 'Sustainable management of sludge in developing countries', Water Science and Technology, vol 49, no 10, pp251-8

Jiménez, B. and Garduño, G. (2001) 'Social, political and scientific dilemmas for massive wastewater reuse in the world', in C. Davis and R. McGinn (eds) Navigating Rough Waters: Ethical Issues in the Water Industry, American Water Works Association, Denver, $\mathrm{CO}$

Jiménez, B. and Wang, L. (2006) 'Sludge treatment and management', in Z. Ujang and M. Henze (eds) Developing Countries: Principles and Engineering, IWA Publishing, London, pp237-92

Juanico, M. and Salgot, M. (2008) 'Northern Mediterranean world', in B. Jiménez and T. Asano (eds) Water Reuse: An International Survey of Current Practice, Issues and Needs, IWA Publishing, London, p648

Keraita, B., Jiménez, B. and Drechsel, P. (2008) 'Extent and implications of agricultural reuse of untreated, partly treated and diluted wastewater in developing countries', Agriculture, Veterinary Science, Nutrition and Natural Resources, vol 3, no 58, p15

Koné, D. (in press) 'Making Urban Excreta and Wastewater Management Contributes to Cities' Economic Development. A Paradigm Shift', Water Policy

Koné, D., Cofie, O., Zurbrugg, C., Gallizzi, K., Moser, D., Drescher, S. and Strauss, M. (2007a) 'Helminth eggs inactivation efficiency by faecal sludge dewatering and cocomposting in tropical climates', Water Research, vol 41, no 19, pp4397-402

Koné, D., Strauss, M. and Saywell, D. (2007b) 'Towards an improved Faecal Sludge Management (FSM)', Proceedings of the 1st International Symposium and Workshop on Faecal Sludge Management (FSM) Policy, final report, Dakar, 9-12 May 2006, Die Eidgenössische Anstalt für Wasserversorgung, Dübendorf, Switzerland

Koottatep, T., Polprasert, C. and Hadsoi, S. (2006) 'Integrated faecal sludge treatment and recycling through constructed wetlands and sunflower plant irrigation', Water Science and Technology, vol 54, pp155-64

Lai, T. (2002) 'Perspectives of peri-urban vegetable production in Hanoi', background paper prepared for the Action Planning Workshop of the CGIAR Strategic Initiative for Urban and Peri-urban Agriculture (SIUPA), Hanoi, 6-9 June, convened by International Potato Center (CIP), Lima, Peru

Mekala, G. D., Davidson, B. A. and Boland, A. (2007) 'Multiple uses of wastewater: A methodology for cost-effective recycling', in S. J. Khan, R. M. Stuetz and J. M. Anderson (eds) Water Reuse and Recycling, University of New South Wales (UNSW) Publishing and Printing Services, Sydney, Australia, pp335-43

Moran, J. (2005) Tropical Dairy Farming: Feeding Management for Small Holder Dairy Farmers in the Humid Tropics, Land Links, Collingwood, Australia

Morel, A. and Diener, S. (2006) Greywater Management in Low and Middle-Income Countries. Review of Different Treatment Systems for Households or Neighbourhoods, Swiss Federal Institute of Aquatic Science and Technology (EAWAG), Dübendorf, Switzerland

Page, A. L. and Chang, A. C. (1994) 'Trace elements of environmental concern in terrestrial ecosystems: An overview', in Transactions of the 15th World Congress of Soil Science, vol 3a, pp568-85. Commission II: Symposia, Acapulco, Mexico, 10-16 July, 1994 
Phuc, P. D., Konradsen, F., Phuong, P. T., Cam, P. D. and Dalsgaard, A. (2006) 'Use of human excreta as fertilizer in agriculture in Nghe An province, Viet Nam', Southeast Asian Journal of Tropical Medicine and Public Health, vol 37, pp222-9

Post, J. (2006) 'Wastewater treatment and reuse in eastern Mediterranean region', Water 2, pp36-41

Qadir, M., Wichelns, D., Raschid-Sally, L., Minhas, P. S., Drechsel, P., Bahri, A. and McCornick, P. (2007) 'Agricultural use of marginal-quality water - opportunities and challenges', in D. Molden (ed) Water for Food, Water for Life. A Comprehensive Assessment of Water Management in Agriculture, Earthscan, London, and International Water Management Institute, Colombo, pp425-57

Raschid-Sally, L., Carr, R. and Buechler, S. (2005) 'Managing wastewater agriculture to improve livelihoods and environmental quality in poor countries', Irrigation and Drainage, vol 54, no 1, pp11-22

Raschid-Sally, L. and Jayakody, P. (2008) 'Drivers and characteristics of wastewater agriculture in developing countries: Results from a global assessment, Colombo, Sri Lanka', IWMI Research Report 127, International Water Management Institute, Colombo

Rosemarin, A. (2004) 'The precarious geopolitics of phosphorous', Down to Earth, 30 June, pp27-34

Sanon, H. O., Kaboré-Zoungrana. C. and Ledin, I. (2007) 'Behaviour of goats, sheep and cattle and their selection of browse species on natural pasture in a Sahelian area', Small Ruminant Research, vol 67, no 1, pp64-74

Scott, C. A., Faruqui, N. I. and Raschid-Sally, L. (eds) (2004) Wastewater Use in Irrigated Agriculture: Confronting the Livelihood and Environmental Realities, CABI Publishing, Wallingford, UK

Silva, N., Chan, M. and Bundy, A. (1997) 'Morbidity and mortality due to ascariasis: re-estimation and sensitivity analysis of global numbers at risk', Tropical Medicine and International Health, vol 2, no 6, pp19-28

Snyman, H. (2008) 'South Africa', in R. LeBlanc, P. Matthews and P. Roland (eds) Global Atlas of Excreta, Wastewater Sludge, and Biosolids Management: Moving Forward the Sustainable and Welcome Uses of a Global Resource, UN-Habitat, Nairobi, pp514-25

Soulié, M. and Tréméa, L. (1991) 'Technologie pour le traitement et la réutilisation des eaux usées dans le bassin méditerranéen', in Proceedings of the 3rd Meeting of the Regional Agency for Environment, Provence - Alpes - Côte d'Azur, pp171-255

State of California (2001) 'Wastewater recycling criteria', an excerpt from the California Code of Regulations, Title 22, Division 4, Environmental Health, Dept. of Health Services, Sacramento, California, June 2001 edition

Strauss, M., Larmie, S. A. and Heinss, U. (1997) 'Treatment of sludges from on-site sanitation - Low-cost options', Water Science and Technology, vol 6, no 35, pp129-36

Toutain B., Guervilly T., Le Masson, A. and Roberge, G. (2006) 'Leçons de quelques essais de régénération des parcours en région sahélienne’, Sécheresse, vol 17, no 1-2, pp72-5

Trang, D., Hien, B., Mølbak, K., Cam, P. and Dalsgaard, A. (2007a) 'Epidemiology and aetiology of diarrhoeal diseases in adults engaged in wastewater-fed agriculture and aquaculture in Hanoi, Vietnam', Tropical Medicine and International Health, vol 12, no 2, pp23-33 
Trang, D., Hien, B., Mølbak, K., Cam, P. and Dalsgaard, A. (2007b) 'Helminth infections among people using wastewater and human excreta in peri-urban agriculture and aquaculture in Hanoi, Vietnam', Tropical Medicine and International Health, vol 12, no 2, pp82-90

United Nations (2003) UN World Water Development Report: Water for People, Water for Life, UNESCO and Berghahn Books, Paris, New York and Oxford

United Nations Human Settlements Programme (2008), in R. LeBlanc, P. Matthews and P. Roland (eds) Global Atlas of Excreta, Wastewater Sludge, and Biosolids Management: Moving Forward the Sustainable and Welcome Uses of a Global Resource, UN-Habitat, Nairobi, p632

WHO (1989) Guidelines for the Safe Use of Wastewater in Agriculture, WHO, Geneva

WHO (2006) Guidelines for the Safe Use of Wastewater, Excreta and Greywater, Volume 2: Wastewater Use in Agriculture, World Health Organization, Geneva

WHO-IDRC (2006) 'Report of the first consultative workshop on the WHO/IDRC project. Non-treatment options for safe wastewater use in poor urban communities', WHO/SDE/WSH/07.03, www.who.int/water_sanitation_health/wastewater/ accraworkshop_wsh0703.pdf

Wolf, J., van Wijk, M. S., Cheng, X., Hu, Y., van Diepen, C. A., Jongbloed, A. W., van Keulen, H., Lu, C. H. and Roetter, R. (2003) 'Urban and peri-urban agricultural production in Beijing municipality and its impact on water quality', Environment and Urbanization, vol 15, no 2, pp141-56

World Resources Institute (2000) World Resources 2000-2001, People and Ecosystems: The Fraying Web of Life, WRI, Washington, DC, http://maps.grida.no/go/graphic/ freshwater_withdrawal_in_agriculture_industry_and_domestic_use/

Yang, H. and Abbaspour, K. (2007) 'Analysis of wastewater reuse potential in Beijing', Desalination, vol 212, pp 238-50 